\title{
Pengaruh Motivasi Kerja dan Pengembangan Karir terhadap Promosi Jabatan di Polsek Bajubang Kabupaten Batanghari
}

\author{
Etty Siswati ${ }^{1}$, Evi Fauzani ${ }^{2}$, Karyadi ${ }^{3}$ \\ ${ }^{1,2,3}$ Sekolah Tinggi Ilmu Ekonomi Graha Karya, Muara Bulian \\ Correspondence email: ettysiswati793@gmail.com
}

\begin{abstract}
Abstrak. Penelitian ini bertujuan untuk mengetahui pengaruh $\left(\mathrm{X}_{1}\right)$ Motivasi Kerja, $\left(\mathrm{X}_{2}\right)$ Pengembangan Karir terhadap (Y) Promosi Jabatan Di Polsek Bajubang Kabupaten Batanghari. Penelitian ini termasuk penelitian deskriptif kuantitatif. Sampel penelitian ini adalah 31 orang. Berdasarkan hasil dari Uji parsial (Uji t). Diperoleh nilai $t_{\text {hitung }}$ untuk $\left(\mathrm{X}_{1}\right)$ Motivasi Kerja sebesar

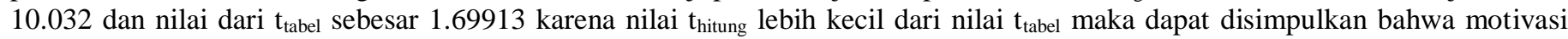
kerja tidak berpengaruh signifikan terhadap kinerja pegawai. Sedangkan $\left(\mathrm{X}_{2}\right)$ Pengembangan Karir diperoleh nilai $\mathrm{t}_{\text {hitung }}$ sebesar 5.977 dan nilai dari $t_{\text {tabel }}$ sebesar 1.69913 karena nilai $t_{\text {hitung }}$ lebih besar dari $t_{\text {tabel }}$ maka dapat disimpulkan bahwa disiplin kerja berpengaruh signifikan terhadap kinerja pegawai. Berdasarkan hasil dari Uji Simultan (Uji F). Diperoleh nilai $F_{\text {hitung }}$ sebesar 19.379 dan nilai $F_{\text {tabel }}$ sebesar 3.93 karena nilai $F_{\text {hitung }}$ lebih besar $F_{\text {tabel }}$ maka dapat disimpulkan bahwa motivasi kerja, disiplin kerja dan kompetensi kerja menunjukan adanya pengaruh yang signifikan terhadap kinerja pegawai. Berdasarkan Hasil dari Koofesien Determinasi $\left(\mathrm{R}^{2}\right)$ didapat nilai Adjusted R Square sebesar 551 dapat disimpulkan persentase pengaruh Motivasi Kerja $\left(\mathrm{X}_{1}\right)$, Penembangan Karir $\left(\mathrm{X}_{2}\right)$ terhadap Kinerja $(\mathrm{Y})$ sebesar $55.1 \%$ dan 44,9\% dipengaruhi oleh variabel - variabel lain yang tidak diteliti dalam penelitian ini.
\end{abstract}

Kata Kunci: Motivasi Kerja, Pengembangan Karir, Promosi Jabatan di Kabupaten Batanghari.

Abstract. This study aims to determine the effect of $\left(X_{1}\right)$ Work Motivation, $\left(X_{2}\right)$ Career Development on $(Y)$ Job Promotion at Polsek Bajubang Kabupaten Batanghari. This research is a quantitative descriptive study. The sample of this study was 31 people. Based on the results of research and discussion, then some of the main points of research conclusions can be explained as follows. Based on the results of the partial test ( $t$ test). Obtained tcount for $\left(X_{1}\right)$ Work Motivation is 10,032 and ttable value is 1.69913 because tcount is smaller than ttable so it can be concluded that work motivation does not significantly influence employee performance. Whereas $\left(X_{2}\right)$ Career Development, the value of tcount is 5,977 and the value of t table is 1,69913 because tcount is greater than ttable, it can be concluded that work discipline has a significant effect on employee performance. Based on the results of the Simultaneous Test (Test F). Obtained Fcount value of 19,379 and Ftable value of 3.93 because the Fcount value is greater than Ftable, it can be concluded that work motivation, work discipline and work competence show a significant influence on employee performance. Based on the results of the Coofesien Determination (R2) obtained an Adjusted R Square value of 551, it can be concluded that the percentage influence of Work Motivation ( $\left.X_{1}\right)$, Career Development ( $\left.X_{2}\right)$ on Performance $(Y)$ of $55.1 \%$ and $44.9 \%$ is influenced by other variables not examined in this study.

Keywords: Work Motivation, Career Development, Job Promotion in Kabupaten Batanghari

\section{PENDAHULUAN}

Dalam masyarakat yang berkembang, Sumber Daya Manusia mempunyai peranan penting dimana Sumber Daya Manusia adalah potensi yang merupakan asset dan berfungsi sebagai modal di dalam organisasi bisnis yang dapat diwujudkan menjadi potensi nyata (real) secara fisik dan non fisik dalam mewujudkan ekstensi organisasi. Pada setiap organisasi/perusahaan faktor tenaga kerja manusia merupakan bagian yang cukup penting dalam pencapaian tujuan perusahaan baik itu perusahaan besar maupun kecil. Jadi bagaimanapun suatu perusahaan memiliki suatu peralatan yang modern dengan teknologi tinggi tetapi menusia merupakan motor penggerak, tanpa manusia perusahaan tidak akan berfungsi.

Suatu organisasi akan berjalan lancar bila semua jasa yang disumbangkan individu pada organisasi mendapat perhatian dan imbalan yang seimbang. As'ad (2003) mengatakan bahwa betapun sempurnanya rencana-rencana organisasi dan pengawasan serta penilaian bila meraka tidak dapat menjalankan tugas dengan minat dan gembira maka suatu perusahaan tidak akan mencapai hasil banyak yang sebenarnya dicapai.

Manusia merupakan sumber daya yang penting dalam upaya mencapai keberhasilan organisasi, dimana sumber daya manusia ini akan menunjang organisasi dengan bakat, kecekapan, keterampilan, kreatifitas dan karyanya. Betapapun sempurnanya aspek tekhnologi dan ekonomi suatu organisasi, tanpa sumber daya manusia sulit kiranya tujuan organisasi akan terwujud.

Polsek Bajubang rupakan suatu lembaga yang melindungi masyarakat dan keaman masyarakat. Untuk mendapatkan kepercayaan oleh masyrakat Polsek Bajubang harus dapat meningkatkan pelayanan yang semaksimal mungkin, salah satu nya dengan cara memberikan motivasi-motivasi kerja kepada karyawan sehingga karyawan dapat bekerja dengan baik dilapangan, Karena karyawan yang berpotensi adalah 
aset berharga bagi suatu perusahaan, maka itu karyawan harus dikelola dengan baik, karena pelayanan yang diberikan oleh karyawan menentukan suatu mutu dan citra suatu lembaga atau dengan kata lain promosi pegawai merupakan salah satu barometer dari mutu pelayanan suatu lembaga.

Pengembangan karir menurut Mondy (2010: 228) pengembangan karir adalah pendekatan formal yang diputuskan perusahaan untuk memastikan bahwa orangorang dengan kualitas dan pengalamaan yang tepat, tersedia saat dibutuhkan.

Pendapat lain dan Mejia (2007 : 267) yang menyatakan "Pengembangan Karir dapat diartikan sebagai upaya formal dan berkelanjutan yang berfokus pada pengembangan karir terhadp karyawan yang lebih baik.

Hal yang serupa diungkapkan oleh $\mathrm{H}$. Handari Nawawi (2008 : 289) yang mengatkan bahwa "Pengembangan Karir adalah usaha yang dilakukan secara formal dan berkelanjutan dengan difokuskan pada peningkatan dan penambahan kemampuan seorang pekerja". Pendapat tersebut dapat di artikan bahwa pengembangan karir adalah usaha formal untuk meningkatkan dan menambah kemampuan seorang pekerja yang dapat membuka kesempatan untuk mencapai suatu rencana karir selama masa bekerja.

Promosi Jabatan terjadi apabila seorang pegawai dipindahkan dari satu pekerjaan lain yang lebih tinggi dalam pembayaran, tanggung jawab dan atau level. Promosi Jabatan yangdilakukan oleh manajemen perusahan memberikan peranan penting bagi setiap karyawan, bahwa setiap menjadikan promosi jabatan menjadi tujuan yang selalu diharapkan Setiawan (2013:3) Irham Fahmi (2016.) Promosi adalah suatu kenaikan pada posissi seorang karyawan dadi posisi sebelumnya ke posisi yang lebih tinggi. Ardana (2012.107) ada beberapa kreteria yang perlu diperhitungkan perusahaan dalam mempormosikan karyawan yaitu Senioritas, kwalipikasi, pendidikan, karsa dan daya cipta, tingkat kejurusan dan supelitas.

Dari uraian latar belakang diatas dapat dirumuskan masalah adalah: 1) Bagaimana Pengaruh Motivasi Kerja Terhadap Promosi Jabatan di Polsek Bajubang Kabupaten Batanghari; 2) Bagaimana Pengaruh Pengembangan Karir Terhadap Promosi Jabatan di Polsek Bajubang Kabupaten Batanghari; 3) Bagaimana Pengaruh Motivasi Kerja dan Pengembangan Karir Terhadap Promosi Jabatan di Polsek Bajubang Kabupaten Batanghari.

Adapun tujuan dari penelitian ini adalah: 1) Untuk Mengetahui Pengaruh Motivasi Kerja Terhadap Promosi Jabatan di Polsek Bajubang Kabupaten Batanghari; 2) Untik Mengetahui Pengaruh Pengembangan Karir terhadap Promosi Jabatan di Polsek Bajubang Kabupaten Batanghari; 3) Untuk Mengetahui Pengaruh Motivasi
Kerja dan Pengembangan Karir Terhadap Promosi Jabatan di Polsek Bajubang Kabupaten Batanghari

\section{METODE \\ Lokasi dan Objek Penelitian}

Penelitian ini dilakukan dengan mengambil lokasi di Polsek Bajubang Kabupaten Batanghari. Dalam penelitian ini yang menjdi objek penelitian adalah anggota Polsek pada Polsek Kabupaten Batanghari.

Lokasi penelitian ini dipilih karena ditemukan masalahmasalah yang berhubungan dengan Motivasi Kerja, Pengembangan Karir, Promosi Jabatan di Polsek Bajubang.

\section{Jenis Penelitian}

Jenis Penelitian yang digunakan dalam penelitian ini adalah bersifat deskritif kualittif.

\section{Alat Analisis Data}

1. Uji Validitas

2. Uji Reliabilitas

\section{Uji Asumsi Klasik}

Model regrsi berganda yang digunakan dalam pengujian hipotesi dikatakan model yang baik apabila model I tersebut memenuhi normalitas data dan terbebas dari asumsi-asumsi klasik, yaitu normalitas, multikolinearitas, autokorelasi dan heteroskedastisitas (Sujianto, 2009).

\section{Uji Normalitas}

Uji normalitas bertujuan untuk menguji apakah dalam model regresi, variabel terikat (dependen) dan variabel bebas (independen) memiliki distribusi normal. Model regresi yang baik adalah jika distribusi data normal atau mendekati normal (Ghozali, 2006). Untuk menguji apakah data terdistribusi normal atau tidak dapat dilakukan dengan analisis grafik dan uji statistik. Analisis grafik merupakan cara yang mudah untuk mendeteksi normalitas yaitu dengan melihat penyebaran data (titik) pada sumbu diagonal dari grafik normal probability plot. Pengambilan keputusan dalam uji normalitas menggunakan analisis grafik ini didasarkan pada:

a. Jika data menyebar di sekitar garis diagonal dan mengikuti garis diagonal, maka model regresi memenuhi asumsi normalitas

b. Jika data menyebar jauh dari garis diagonal dan atau tidak mengikuti arah garis diagonal, maka model regresi tidak memenuhi asumsi normalitas.

Menurut Ghozali (2006), uji normalitas dengan grafik dapat menyesatkan kalau tidak hati-hati secara visual kelihatan normal, padahal secara statistik dapat sebaliknya. Oleh sebab itu dianjurkan disamping uji grafik dilengkapi uji statistik. Uji statistik sederhana yang dapat digunakan untuk menguji normalitas residual 
adalah uji statistik non-parametrik Kolmogorov-Smirnov (K-S).

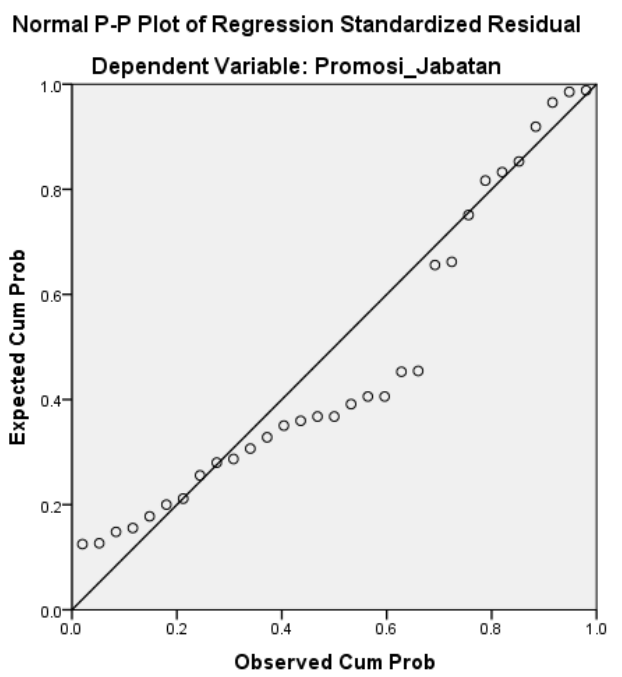

Uji multikolinieritas bertujuan untuk menguji apakah model regresi ditemukan adanya korelasi antar variabel bebas (independen). Model regresi yang baik seharusnya tidak terjadi korelasi di antara variabel bebas. Jika variabel bebas saling berkorelasi, maka variabelvariabel tersebut tidak ortogonal. Variabel ortogonal adalah variabel bebas yang nilai korelasi antar sesama variabel independen sama dengan nol (Ghozali, 2006). Pengujian ada atau tidaknya multikolinieritas di dalam model regresi dapat dilakukan dengan melihat nilai tolerance dan nilai variance inflation factor (VIF) . Kedua ukuran ini menunjukkan setiap variabel independen manakah yang dijelaskan oleh variabel independen lainnya. Nilai cutoff yang umum dipakai untuk menunjukkan adanya multikolinieritas adalah nilai tolerance $\leq 0,10$ atau nilai VIF $\geq 10$ (Ghozali,2006).

\section{Uji Multikolinieritas}

Tabel 1. Nilai Tolerance dan VIF

Coefficients $^{\mathrm{a}}$

\begin{tabular}{|c|c|c|c|c|c|c|c|}
\hline \multirow{2}{*}{ Model } & \multicolumn{2}{|c|}{ Unstandardized Coefficients } & \multirow{2}{*}{$\frac{\text { Standardized Coefficients }}{\text { Beta }}$} & \multirow[t]{2}{*}{$\mathrm{t}$} & \multirow[t]{2}{*}{ Sig. } & \multicolumn{2}{|c|}{ Collinearity Statistics } \\
\hline & B & Std. Error & & & & Tolerance & VIF \\
\hline (Constant) & -2.164 & 5.851 & & -.370 & .714 & & \\
\hline 1 Motivasi_Kerja & .171 & 166 & .127 & 1.032 & .311 & 986 & 1.014 \\
\hline Pengembangan_Karir & .912 & .153 & .737 & 5.977 & .000 & .986 & 1.014 \\
\hline
\end{tabular}

a. Dependent Variable: Promosi_Jabatan

\section{Uji Heteroskedastisitas}

Uji heteroskedastisitas bertujuan untuk menguji apakah dalam model regresi terjadi ketidaksamaan variance dari residual satu pengamatan ke pengamatan yang lain (Ghozali,2006). Jika variance dari residual satu pengamatan ke pengamatan yang lain tetap, maka disebut homoskedastisitas dan jika berbeda disebut heteroskedastisitas. Model regresi yang baik adalah yang homoskedastisitas atau tidak terjadi heterokdastisitas. Untuk mendeteksi ada atau tidaknya heteroskedastisitas dapat dilakukan dengan melihat grafik Plot antara niali prediksi variabel terikat (dependen) dengan nilai residualnya. Dasar analisis grafik Plot adalah sebagai berikut:

a. Jika ada pola tertentu, seperti titik-titik yang ada membentuk pola tertentu yang teratur maka mengindikasikan telah terjadi heteroskedastisitas

b. Jika tidak ada pola yang jelas, serta titik-titik menyebar di atas dan di bawah angka 0 pada sumbu Y, maka tidak terjadi heteroskedastisitas (Ghozali, 2006).

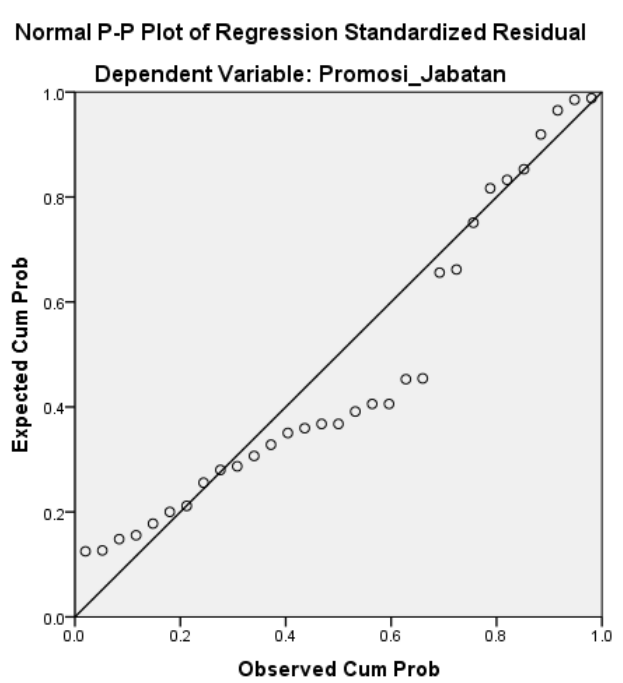

\section{Uji Autokorelasi}

Uji Autokorelasi adalah untuk menguji apakah dalam persamaan regresi ditemukan adanya korelasi antara kesalahan penggangu pada periodet dengan kesalahan pengganggu periode t-I. Dalam penelitian ini digunakan uji Durbin Watson dengan dasar pengambilan keputusan sebagai berikut : 
Etty Siswati et al, Pengaruh Motivasi Kerja dan Pengembangan Karir terhadap Promosi Jabatan di Polsek Bajubang Kabupaten Batanghari

Model Summary ${ }^{\mathrm{b}}$

\begin{tabular}{|l|r|r|r|r|r|}
\hline Model & R & R Square & Adjusted R Square & Std. Error of the Estimate & Durbin-Watson \\
\hline 1 & $.762^{\mathrm{a}}$ & .581 & .551 & 2.42864 & 1.667 \\
\hline
\end{tabular}

a. Predictors: (Constant), Pengembangan_Karir, Motivasi_Kerja

b. Dependent Variable: Promosi_Jabatan

\section{Analisis Regresi Linear Berganda}

Menurut Rachman Rijono (2015:70), Analisis regresi berganda merupakan alat analisis yang digunakan untuk mengetahui pengaruh antara $X_{1}$ (Motivasi Kerja), $\mathrm{X}_{2}$ (Pengembangan Karir) Terhadap $\mathrm{Y}$ (Promosi Jabatan). Untuk mendapatkan gambaran yang jelas tentang pengaruh variabel yang ada maka digunakan alat analisis data. Dalam penelitian ini alat analisis yang digunakan adalah dengan menggunakan Regresi Linear Berganda, Dimana analisis ini digunakan untuk mengetahui pengaruh dari variabel bebas terhadap variabel terikat. Adapun model dari Regresi Linear Berganda adalah sebagai berikut

$$
\begin{array}{ll}
\mathrm{Y}=\mathrm{a}+\mathrm{b}_{1} \cdot \mathrm{X}_{1} & +\mathrm{b}_{2} \cdot \mathrm{X}_{2}+\mathrm{e} \\
\text { Dimana: } & =\text { Promosi Jabatan } \\
\mathrm{Y} & =\text { Konstanta } \\
\mathrm{a} & =\text { Motivasi Kerja } \\
\mathrm{b}_{1} \cdot \mathrm{X}_{1} & =\text { Pengembangan Karir } \\
\mathrm{b}_{2} \cdot \mathrm{X}_{2} & =\text { Eror } \\
\mathrm{e} &
\end{array}
$$

\section{HASIL DAN PEMBAHASAN}

Hasil Penelitian regresi linier berganda dengan program SPSS Versi 20 dari tabel koefisien di peroleh persamaan sebagai berikut :

Tabel 3. Hasil Regresi

Coefficients $^{\text {a }}$

\begin{tabular}{|l|r|r|r|r|r|}
\hline \multirow{2}{*}{ Model } & \multicolumn{2}{|c|}{ Unstandardized Coefficients } & Standardized Coefficients & \multirow{2}{*}{ Sig. } \\
\cline { 2 - 5 } & \multicolumn{1}{|c|}{$\mathrm{B}$} & Std. Error & Beta & -.370 & \\
\hline (Constant) & -2.164 & 5.851 & .714 \\
1 Motivasi_Kerja & .171 & .166 & .127 & 1.032 \\
Pengembangan_Karir & .912 & .153 & .737 & .311 \\
\hline
\end{tabular}

a. Dependent Variable: Promosi_Jabatan

Untuk melihat pengaruh Motivasi Kerja dan Pengembangan Karir terhadap Promosi Jabatan, maka digunakan analisa regresi linear berganda. Berdasarkan hasil pengolahan data dengan bantuan program SPSS 20.0 dapat dilihat pada tabel berikut.

Dari data diatas dapat dibuat persamaan regresi linier berganda sebagai berikut:

$$
\begin{aligned}
Y & =a+b_{1} X_{1}+b_{2} X_{2} \\
& =2.164+0,171 X_{1}+0.912 X_{2}
\end{aligned}
$$
bahwa :

Dari persamaan tersebut dapat diambil kesimpulan

a. Konstanta sebesar -2.164 menyatakan bahwa jika tidak ada Motivasi Kerja Vertikal $\left(\mathrm{X}_{1}\right)$, dan Pengembangan Karir $\left(\mathrm{X}_{2}\right)$ maka Promosi Jabatan .adalah sebesar -2.164

b. Koefisien regresi Motvasi Kerja $\left(\mathrm{X}_{1}\right)$ Naik satu satuan maka variabel Promosi Jabatan akan meningkat sebesar 0,171 dengan asumsi Variabel Pengembangan Karir $\left(\mathrm{X}_{2}\right)$ tetap.

c. Koefisien regresi Pengembangan Karir $\left(\mathrm{X}_{2}\right)$ naik satuan satuan variabel Promosi Jabatan akan meningkat sebesar 0,912 dengan asumsi Variabel Motivasi Kerja $\left(\mathrm{X}_{1}\right)$ tetap

\section{Uji Partial Dengan t-Test}

Uji statistik t pada dasarnya digunakan untuk melihat pengaruh variabel independen terhadap variabel dependen secara parsial. Dimana pada penelitian ini untuk melihat secara parsial/individual.

\section{Penaruh Motivasi Kerja Terhadap Promosi Jabatan di} Polsek Bajubang Kabupaten Batanghari

Dengan menggunakan t-test, diperoleh nilai $t_{\text {hitung }}$ variabel $\mathrm{X}_{1}$ Motivasi Kerja sebesar 1.032 sedangkan $\mathrm{t}_{\text {tabel }}$ pada taraf kepercayaan $95 \%$ (signifikansi $5 \%$ atau 0,05 ) dan derajat bebas $(\mathrm{df})=\mathrm{N}-\mathrm{k}-1=32-2-1=29$, dimana $\mathrm{N}$ = jumlah sampel, dan $\mathrm{k}=$ jumlah variabel independen yaitu sebesar 1.69913. Dengan demikian $t_{\text {hitung }}=1.032<$ $\mathrm{t}_{\text {tabel }}=1.69913$ artinya Motivasi Kerja Anggota Kepolisian Polsek Bajubang tidak berpengaruh terhadap Promosi Jabatan

\section{Pengaruh Pengembangan Karir Terhadap Promosi Jabatan di Polsek Bajubang Kabupaten Batanghari \\ Sedangkan, diperoleh nilai thitung variabel $\mathrm{X}_{2}$ Pengembangan Karir sebesar 5.977 sedangkan $t_{\text {tabel }}$ adalah sebesar 1.69913 dengan demikian $t_{\text {hitung }}=5.977>$ $\mathrm{t}_{\text {tabel }}=1.69913$ Berdasarkan analisis di atas disimpulkan bahwa Pegembangan Karir Anggota Kepolisian}


Bajubang berpengaruh signifikan terhadap Promosi Jabatan

Pengaruh Motivasi Kerja dan Pengembangan karir terhadap Promosi Jabatan di Polsek Bajubang Kabupaten Batanghari

\section{Uji Simultan Dengan F-Test (Anova ${ }^{\text {b }}$ )}

Uji $F$ untuk menentukan apakah secara serentak/bersama-sama variabel independen mampu menjelaskan variabel dependen dengan baik atau apakah variabel independen secara bersama-sama mempunyai pengaruh yang signifikan terhadap variabel dependen. Pada tabel Anova dapat dilihat pengaruh variabel independen Motivasi Kerja dan Pengembangan Karir terhadap variabel dependen Promosi Jabatan pada Polsek Bajubang secara simultan/bersama. Dimana setelah dilakukan penganalisaan dengan SPSS 20.0 maka didapat output sebagai berikut:

Tabel 4. Hasil Uji Simultan (Uji F) ANOVA $^{\mathrm{a}}$

\begin{tabular}{|ll|r|r|r|r|r|}
\hline Model & \multicolumn{1}{|c|}{ Sum of Squares } & \multicolumn{1}{c|}{ df } & Mean Square & F & \multicolumn{1}{c|}{ Sig. } \\
\hline \multirow{2}{*}{1} & Regression & 228.606 & 2 & 114.303 & 19.379 & \\
& Residual & 165.152 & 28 & 5.898 & & \\
& Total & 393.758 & 30 & & & \\
\hline
\end{tabular}

a. Dependent Variable: Promosi_Jabatan

b. Predictors: (Constant), Pengembangan_Karir, Motivasi_Kerja

Uji signifikansi simultan/bersama-sama (uji statistik F) menghasilkan nilai $\mathrm{F}$ hitung sebesar 19.379 variabel independen yaitu variabel Motivasi Kerja $\left(\mathrm{X}_{2}\right)$ dan Variabel Pengembangan Karir $\left(\mathrm{X}_{2}\right), \mathrm{F}_{\text {hitung }}=19.379$ $>\mathrm{F}_{\text {tabel }}=3.93$ dengan tingkat signifikansi 0,000. karena probabilitasnya signifikansi jauh lebih kecil dari sig <
0,05, maka model regresi dapat dipergunakan untuk memprediksi Promosi Jabatan Anggota Kepolisian Bajubang, atau dapat dikatakan bahwa Motivasi Kerja $\left(\mathrm{X}_{1}\right)$, dan Pengembangan Karir $\left(\mathrm{X}_{2}\right)$ secara bersamasama berpengaruh terhadap Promosi Jabatan di Polesek Bajubang.

Tabel 5. Uji Koefisien Determinasi Model Summary

\begin{tabular}{|l|r|r|r|r|}
\hline Model & R & R Square & Adjusted R Square & Std. Error of the Estimate \\
\hline 1 & $.762^{\mathrm{a}}$ & .581 & .551 & 2.42864 \\
\hline
\end{tabular}

a. Predictors: (Constant), Pengembangan_Karir, Motivasi_Kerja

Pada hasil penelitian ditemukan bahwa pengaruh Motivasi Kerja , Pengembangan Karir terhadap Promosi Jabatan di Polsek Bajubang sangat kuat sebesar $(\mathrm{r}=$ 0,551). Koefisien determinasi atau angka $\mathrm{R}$ square adalah sebesar 0,551. Nugroho (2005), menyatakan untuk regresi linear berganda sebaiknya menggunakan $\mathrm{R}$ square yang sudah disesuaikan atau tertulis Adjusted $R$ square, karena disesuaikan dengan jumlah variabel independen yang digunakan, dimana jika variabel independent 1 (satu) maka menggunakan $\mathrm{R}$ square dan jika telah melebihi 1 (satu) menggunakan adjusted $\mathrm{R}$ square. Adjusted R square adalah sebesar 0,551 hal ini berarti 55,1\% dari variasi variabel dependent Promosi Jabatan di Polsek Bajubang Kabupaten Batanghari dijelaskan oleh variabel independen Motivasi Kerja,Pengembangan Karir sedangkan sisanya sebesar $44,9 \%(100 \%-55,1 \%)$ variabel-variabel lain diluar variabel yang tidak diteliti.

\section{SIMPULAN}

1. Pengaruh Motivasi Kerja Terhadap Promosi Jabatan di Polsek Bajubang Kabupaten Batanghari

Dengan menggunakan t-test, diperoleh nilai thitung variabel $\mathrm{X}_{1}$ Motivasi Kerja sebesar 1.032 sedangkan ttabel pada taraf kepercayaan 95\% $($ signifikansi $5 \%$ atau 0,05$)$ dan derajat bebas $(\mathrm{df})=$ $\mathrm{N}-\mathrm{k}-1=32-2-1=29$, dimana $\mathrm{N}=$ jumlah sampel, dan $\mathrm{k}=$ jumlah variabel independen yaitu sebesar 1.69913. Dengan demikian $\mathrm{t}_{\text {hitung }}=1.032<\mathrm{t}_{\text {tabel }}=$ 1.69913 artinya Motivasi Kerja Anggota Kepolisian Polsek Bajubang tidak berpengaruh terhadap Promosi Jabatan

2. Pengaruh Pengembangan Karir Terhadap Promosi Jabatan di Polsek Bajubang Kabupaten Batanghari

Sedangkan, diperoleh nilai thitung variabel X2

Pengembangan Karir sebesar 5.977 sedangkan ttabel adalah sebesar 1.69913 dengan demikian $\mathrm{t}_{\text {hitung }}=$ $5.977>t_{\text {tabel }}=1.69913$ Berdasarkan analisis di atas disimpulkan bahwa Pegembangan Karir Anggota Kepolisian Bajubang berpengaruh signifikan terhadap Promosi Jabatan

3. Pengaruh Motivasi Kerja Dan Pengembangan Karir terhadap Promosi Jabatan di Polsek Bajubang Kabupaten Batanghari

Uji signifikansi simultan/bersama-sama (uji statistik F) menghasilkan nilai $F$ hitung sebesar 19.379 variabel independen yaitu variabel Motivasi Kerja $\left(\mathrm{X}_{2}\right)$ dan Variabel Pengembangan Karir $\left(\mathrm{X}_{2}\right), \mathrm{F}_{\text {hitung }}=$ 
$19.379>\mathrm{F}_{\text {tabel }}=3.93$ dengan tingkat signifikansi 0,000. karena probabilitasnya signifikansi jauh lebih kecil dari sig $<0,05$, maka model regresi dapat dipergunakan untuk memprediksi Promosi Jabatan Anggota Kepolisian Bajubang, atau dapat dikatakan bahwa Motivasi Kerja $\left(\mathrm{X}_{1}\right)$, dan Pengembangan Karir $\left(\mathrm{X}_{2}\right)$ secara bersama-sama berpengaruh terhadap Promosi Jabatan di Polesek Bajubang.

Pengaruh Motivasi Kerja , Pengembangan Karir terhadap Promosi Jabatan di Polsek Bajubang sangat kuat sebesar $(r=0,551)$. Koefisien determinasi atau angka $\mathrm{R}$ square adalah sebesar 0,551 . Nugroho (2005), menyatakan untuk regresi linear berganda sebaiknya menggunakan $\mathrm{R}$ square yang sudah disesuaikan atau tertulis Adjusted $\mathrm{R}$ square, karena disesuaikan dengan jumlah variabel independen yang digunakan, dimana jika variabel independent 1 (satu) maka menggunakan $\mathrm{R}$ square dan jika telah melebihi 1 (satu) menggunakan adjusted R square. Adjusted R square adalah sebesar 0,551 hal ini berarti $55,1 \%$ dari variasi variabel dependent Promosi Jabatan di Polsek Bajubang dijelaskan oleh variabel independen Motivasi Kerja,Pengembangan Karir sedangkan sisanya sebesar $55,1 \%(100 \%-55,1 \%)$ variabelvariabel lain diluar variabel yang tidak diteliti.

\section{DAFTAR PUSTAKA}

Bambang Wahyudi, 2012, Manajemen Sumber Daya Manusia.Sulita,Bandung

Bernadin dan Russel, 2012 ,Human Resources Management : An. Experiental Approach ,Gramedia Pustaka, Jakarta.

Dessler, Gary. 2009. Manajemen Sumber Daya Manusia, Edisiesepuluh

Jilid2.Jakarta:PT.MacananJaya.

Dessler, Gary. (2011). Human Resource Management: Global Edition. Pearson Higher Education

Henry Simamora. 2004. Manajemen Sumber Daya Manusia. Edisi Ke-3. STIE YKPN.

Yogyakarta.

Handoko, 2014,Manajemen Personalia dan Sumber Daya Manusia.BPFE

Hasibuan, Malayu. 2006. Manajemen SumberDaya Manusia Edisievisi.Jakarta:BumiAksara

Nawawi, Hadari. 2008. Manajemen Sumber Daya Manusia Untuk Bisnis Yang Kompetitif. Yogyakarta :Gadjah Mada Univesity Press. A.A.Anwar Prabu

Mangkunegara. 2011. Manajemen Sumber Daya Manusia Perusahaan . PT.Remaja Rosda Karya, Bandung

Robbins, Stephen P.; Judge, Timothy A. 2008. Perilaku Organisasi Buku 1,Jakarta: Salemba Empat.

Sugiyono. (2012). Statistika untuk penelitian . Cetakan ke 20, CV. Alfa Beta Bandung
Malayu P. Hasibuan ,(2007). Manajemen Sumber Daya Manusia, Bumi Askara : Jakarta

Stephen Robbin. (1990). Organization Theory, Structure Design And Application, Third Edition, Practice , Hall, Inc Engee Wood

Sugiyono (2011).Metode Penelitian Kuantitatif Kualitatif Dan R\&D.Bandung: CV. Alfabeta

Singarimbun, Masri \& Effendi Sofian. 2009. Metode Penelitian Survai.Jakarta : LP3ES

Umi Narimawati.(2007).Riset Manajemen Sumber Daya Manusia,Agung Media : Jakarta

Sumantri,(2016) Pengaruh Kompetensi Kerja Karyawan Terhadap Produktivitas Kerja Karyawan Pada PT. Perkebunan Nusantara VI Unit Usa Kabupaten Batanghari Jurnal EKOTRAS UNES Padang. 